\title{
Compensating Wage Differentials with Unemployment: Evidence from China
}

\author{
Xiaoqi Guo · James K. Hammitt
}

Accepted: 25 May 2008 / Published online: 17 June 2008

(C) Springer Science+Business Media B.V. 2008

\begin{abstract}
We estimate the economic value of mortality risk in China using the compensating-wage-differential method. We find a positive and statistically significant correlation between wages and occupational fatality risk. The estimated effect is largest for unskilled workers. Unemployment reduces compensation for risk, which suggests that some of the assumptions under which compensating wage differentials can be interpreted as measures of workers' preferences for risk and income are invalid when unemployment is high. Workers may be unwilling to quit high-risk jobs when alternative employment is difficult to obtain, violating the assumption of perfect mobility, or some workers (e.g., new migrants) may be poorly informed about between-job differences in risk, violating the assumption of perfect information. These factors suggest our estimates of the value per statistical life (VSL) in China, which range from approximately US $\$ 30,000$ to US $\$ 100,000$, may be biased downward. Alternative estimates adjust for heterogeneity of risk within industry by assuming that risk is concentrated among low-skill workers. These estimates, which are likely to be biased downward, range from US\$7,000 to US\$20,000.
\end{abstract}

Keywords China $\cdot$ Compensating wage differential $\cdot$ Mortality risk $\cdot$ Value per statistical life $\cdot$ Hedonic wage

JEL Classifications $\mathrm{I} 10 \cdot \mathrm{J} 17 \cdot \mathrm{J} 28$

\section{Introduction}

The monetary value of reduced mortality risk, often referred to as the value per statistical life (VSL), is an important parameter for benefit-cost analysis of environmental- and

X. Guo

Agricultural, Environmental and Development Economics, Ohio State University, Columbus, OH, USA

J. K. Hammitt (凶)

Center for Risk Analysis,

Harvard University, 718 Huntington Avenue, Boston, MA 02115, USA

e-mail: jkh@harvard.edu 
public-health policies. The most common and accepted method for estimating this value is through analysis of compensating wage differentials, i.e., incremental wages associated with occupational fatality risk. While many wage-differential studies have been conducted for the United States, United Kingdom, Canada, and other high-income countries, only a few have been conducted for middle- and lower-income economies. In their comprehensive review, the only middle- and lower-income economies for which Viscusi and Aldy (2003) identify studies are Hong Kong, India, South Korea, and Taiwan. The small number of estimates for lower-income countries reflects difficulty in obtaining comprehensive and accurate data on workers' wages, productivity-related characteristics (e.g., education, work experience), and occupational fatality risks.

Given the lack of available estimates, benefit-cost analysts have often adopted the humancapital method (e.g., World Bank 1997) that estimates the value of risk reduction by the future productivity (estimated by wages) lost upon death. Human-capital values underestimate VSL since they exclude the value of non-productive activities (e.g., leisure) and typically exclude the value of unpaid work (e.g., housekeeping). Alternatively, estimates have been based on extrapolation from estimates for higher-income countries but these are subject to substantial uncertainties about the appropriate adjustments for differences in income, economic structure, and other factors (e.g., Chestnut et al. 1997; Stevens et al. 2005). Recently, several stated-preference estimates have become available (e.g., Hammitt and Liu 2004; Liu et al. 2005; Hammitt and Zhou 2006; Wang and Mullahy 2006) but stated-preference estimates are often viewed as less reliable than wage-differential and other revealed-preference estimates.

We report here what is perhaps the first compensating-wage-differential study in mainland China, thus offering policy makers potentially more defensible and accurate estimates of the value of mortality risk. Moreover, we examine how the estimated VSL depends on potential disequilibrium in the labor market associated with unemployment. Conventional applications of the compensating-wage-differential method assume perfectly competitive labor markets in which workers are free to choose from among multiple jobs offering different wages and fatality risks. Standard theory does not predict how compensation for risk depends on the level of unemployment, which limits workers' abilities to choose among jobs. As described below, compensation for risk may be smaller in a labor market with higher unemployment. We test for this effect using province-level unemployment rates as a proxy for the restricted availability of alternative job opportunities. We find that the marginal effect of occupational fatality risk on the log of wages decreases convexly with the unemployment rate. Workers in areas with higher unemployment receive lower compensation per unit risk. The estimated effect is substantial: in our full-sample model, the estimated incremental compensation for a 1 per 10,000 risk increment ranges from $5.5 \%$ of wages with no unemployment to near zero with $8 \%$ unemployment.

Our measure of occupational risk is the rate of fatal injuries by industry. We find stronger evidence of compensating wage differentials for unskilled workers and for skilled and unskilled workers than for professionals and office workers, which is not surprising since skilled and unskilled workers are likely to face larger occupational fatality risks than other workers. Using industry-average fatality rate as the measure of worker risk, our estimates of VSL range from approximately US\$30,000 to \$US100,000. Using alternative risk variables that assume fatal occupational risks are concentrated among skilled and/or unskilled workers, our estimates of VSL are substantially smaller, about US $\$ 7,000$ to US $\$ 20,000$, since the estimated inter-industry differences in wages are assumed to compensate for larger estimated inter-industry differences in risk.

The paper is organized as follows. Section 2 describes the standard hedonic-wage theory and the effects of relaxing the assumption of perfectly competitive labor markets. The worker 
and risk data are described in Sect. 3. Section 4 reports the empirical estimates and Sect. 5 concludes.

\section{Theory and Econometric Model}

More than 200 years ago, Smith (1776) wrote in The Wealth of Nations: "The wages of labor vary with the ease or hardship, the cleanliness or dirtiness, the honorableness or dishonorableness of the employment." Rosen (1974) developed the model of hedonic prices in pure competition. The compensating-wage-differential method is an application of hedonic-pricing theory in the labor market. In a perfectly competitive labor market, after adjusting for human capital and other wage-affecting factors, we anticipate that workers facing higher occupational mortality and morbidity risks receive higher wages in equilibrium. To attract workers, the dangerous, dirty, and difficult jobs must offer higher wages than the safe, clean, and easy jobs.

\subsection{The Standard Model}

Rosen's (1974) model assumes that observed labor-market outcomes represent an equilibrium determined by workers' preferences and firms' tradeoffs between job safety and wages. At equilibrium, workers choose among the available jobs those that maximize their utility, which implies a tangency between each worker's indifference curve and his employer's offer curve (reflecting alternative wage/risk combinations yielding equal profit). Researchers do not observe workers' indifference curves or firms' offer curves but only the market outcomes. The compensating-wage-differential method attempts to estimate the wage-risk locus, $w(p)$, that reflects the joint influence of labor supply and demand on the market equilibrium.

Most of the literature on the wage-differential method focuses on valuing mortality risk by estimating compensating differentials for occupational risk. Consider a modified version of the wage-risk expression from Viscusi and Aldy (2003):

$$
g\left(w_{i}\right)=\alpha+H_{i}^{\prime} \beta_{1}+X_{i}^{\prime} \beta_{2}+\gamma_{1} p_{i}+\gamma_{2} q_{i}+\varepsilon_{i},
$$

where $w_{i}$ is worker $i$ 's wage rate, $g\left(w_{i}\right)$ is a linear or nonlinear transformation of $w_{i}, \alpha$ is a constant, $H$ is a vector of worker characteristics, $X$ is a vector of job characteristics, $p_{i}$ and $q_{i}$ are the occupational fatal- and nonfatal-injury risks associated with worker $i$ 's job, and $\varepsilon_{i}$ is a random error term including unmeasured factors influencing worker $i$ 's wage rate. Interaction terms between risk and worker or job characteristics such as compensation in the event of injury can also enter the equation. Most often, $w_{i}$ or the natural logarithm of $w_{i}$ is used as the dependent variable. VSL is the local slope of the wage-risk locus, $w(p)$, which is equal to the marginal rate of substitution between wage and risk, $d w / d p$. VSL may vary with risk, wage, and worker characteristics.

\subsection{The Assumption of a Perfectly Competitive Labor Market}

The perfectly competitive labor market is an idealization that may be rarely encountered in practice. Perfect competition requires free entry of workers and employers, perfect mobility of workers, and that both workers and employers have perfect information about risk and other job characteristics. Rosen's theory does not predict how wage differentials are affected when these assumptions are violated. 
One factor leading to imperfectly competitive labor markets is workers' imperfect information about how occupational risks differ among jobs. In the absence of effective regulation to reveal information, employers may conceal risks from workers, especially when the fatality or injury risks are high. Workers (especially new entrants to the labor market) may have limited information about workplace safety at their current job and in alternative jobs. They may underestimate the risks they face and accept lower wages than if they perceived risk more accurately (Viscusi and Aldy 2003). In this case, workers' indifference curves would be flatter and the wage-risk curve $w(p)$ could be flatter. After working for a period of time, workers may learn more about the job hazards they face and quit a job that they learn to be more hazardous than initially perceived. In the US, Viscusi (1979) found that the injury rate is an important and positive determinant of industrial aggregate quit rates and the probabilities of individual workers quitting, and that workers' perceptions of job hazards significantly affect their intentions to change jobs. Liu and Hammitt (1999) found a similar positive relationship between quitting intentions and perceived job risk among petrochemical workers in Taiwan.

Another factor limiting labor-market competition is high unemployment, reflecting a surplus of labor supply when workers are not perfectly mobile. The labor surplus may suppress market wages, shifting $w(p)$ downward, as firms shift to higher profit curves and workers shift to lower indifference curves. Rosen's theory does not predict how the shape of $w(p)$ would change in this circumstance. In meta-analyses of wage-differential studies, Mrozek and Taylor (2002) and Viscusi and Aldy (2003) found no statistically significant effect of unemployment on wages but did not test for an effect on compensation for risk.

Purse (2004) criticized the perfect mobility assumption: " "If workers do not have freedom to change jobs when faced with unacceptable risks arising from their work, the presumed imperative placed on employers by the market to compensate them is correspondingly reduced.... In the real world, workers are not at complete liberty to change jobs whenever they feel inclined to do so." He also wrote: "when confronted with a higher level of unemployment, workers, especially those with low education and few marketable skills, may be much less likely to quit their job, irrespective of whether it is hazardous or not." More formally, assume the worker's payoff from his current job is $\left(1-p_{1}\right) w_{1}$, where $p_{1}$ is the fatality risk and $w_{1}$ is the wage. His expected payoff if he quits his current job and searches for a better one is $q\left(1-p_{2}\right) w_{2}$, where $q$ is the probability of finding a new job and $p_{2}$ and $w_{2}$ are the risk and wage in the new job. Even when $\left(1-p_{2}\right) w_{2}$ is greater than $\left(1-p_{1}\right) w_{1}$, the expected payoff from quitting will be smaller than the current payoff if $q$ is small enough, in which case the worker will not quit his current job. If many workers perceive a small probability of finding another job, the $w(p)$ curve may be flatter than if workers can change jobs freely with a high probability of obtaining a new job. If this argument is correct, the market trade-off between wage and risk $w(p)$ may be flatter under limited labor mobility and high unemployment.

There is little empirical evidence on how labor-market imperfections affect the relationship between risk and wages. Viscusi and Aldy (2003) found that union workers received greater compensating differentials for mortality risk than non-union workers in nine of the ten US studies that examined this effect. Viscusi (1980) demonstrated theoretically that a firm with monopsony power would provide less work safety than the social optimum when the marginal worker is less willing than the average worker to accept lower wages for greater safety. In this case, union bargaining on behalf of the average worker may promote social efficiency. Unions may also obtain and disseminate information about risk to union members

${ }^{1}$ See Dorman (1996) for other critiques of the compensating-wage-differential method. 
(Viscusi 1979; Olson 1981; Dillingham and Smith 1984). Viscusi (1980, Table 2) found union members received greater compensation for risk using either subjective or objective estimates of fatal and nonfatal occupational risk. These results suggest that the estimated wage differential received by union workers is a more consistent estimate of VSL and that estimates for non-union workers are biased downward. Some studies have found that nonunion workers receive no compensation or negative compensation for risk (e.g., Viscusi 1980; Dorsey 1983).

In this paper, we examine the effects of workers' imperfect mobility and imperfect risk information on compensating wage differentials in markets with unemployment. In China, labor mobility was very low before the beginning of the economic transition. The residential registration (hukou) system impeded moving from one city to another and from rural to urban areas. Since the economic transition began, the registration system has been gradually discarded. During the 1990s, labor mobility increased but was restrained by the registration system.

Chinese labor markets during the 1990s were characterized by high unemployment. Estimates suggest that urban unemployment rates increased from the early 1990s to 2002 (Giles et al. 2005). Due to the historical effect of the registration system on labor mobility, the high unemployment rates and the lack of social assistance systems during this period, workers facing high occupational risks might have been reluctant to leave their jobs. Thus, the compensating wage differential for occupational injury risk may have been weak or absent.

High unemployment rates may also be correlated with workers' lack of information about occupational risks. During the 1980s and 1990s, provinces where the economic transition began earlier, such as Gongdong, experienced an influx of job-seeking migrants. For these provinces, high local unemployment may have been at least partially caused by increases in labor supply. New workers such as migrants may have little information about betweenjob risk differences. The absence of regulations requiring employers to reveal job-related risks and of unions with the power to press employers to reveal risk information may have aggravated this market imperfection. Thus, an influx of new workers may both increase unemployment and reduce the market compensation for risk.

To account for regional differences in Chinese labor markets we use regional (provincelevel) unemployment rates as a proxy for reduced employment opportunities in our wage-risk model. We expect that both wages and compensating wage differentials for occupational risks are inversely related to regional unemployment.

\section{Data}

Estimation of the wage-risk model (Equation 1) requires data on individual worker characteristics, wages, and occupational-injury risks. Although such data are rare in China, we are able to combine information on workers' wages and other characteristics from a nationwide sample with national data on occupational fatalities.

\subsection{Worker Data}

Data on individual workers are from the Chinese Household Income Project conducted in 1995 by Riskin et al. (2000). This study includes separate samples of urban and rural residents selected from larger samples drawn by the State Statistical Bureau. We use data from the urban individual data set, which includes 21,698 respondents in 11 provinces. Variables include human-capital variables, industry (sector), occupation, wage, and job characteristics. 
Workers' compensation characteristics are not included because China's system did not develop until after these data were collected (city- and county-level insurance funds for work-related injury were first established at the end of 1994 but regulations were not issued until 2004). We restrict our sample to full-time workers, excluding respondents who were full-time students, homemakers, unable to work because of disability, unemployed at any time during 1995, and those earning less than 1000 yuan (US\$125) that year (about 1\% of the sample). The remaining data include about 10,165 workers. Descriptive statistics are reported in Table 1 .

Occupation is described by category: owner of private enterprise, head or division head of institution, professional or technical worker, office worker, skilled worker, unskilled worker, and other. To reduce bias from omitted variables, we supplement our full-sample estimates using subsamples of skilled and unskilled workers who are likely to face higher occupational risks than other categories of workers. As shown in Table 1, skilled and unskilled workers earn less and experience harsher working environments on average than the full sample. Larger fractions of skilled and unskilled workers work underground or underwater (UNDERGW), are exposed to high temperatures (TEMPER) and toxic chemicals (TOXIC), and report dissatisfaction with their work environments (DISSAT).

A limitation of these data is that they include only formal urban residents with registration (hukou) and thus exclude migrants. Many migrants (especially "peasant workers") are relatively young and poorly educated. They often take lower-paid and less attractive jobs such as construction worker, maid, and waiter. These migrants may be willing to accept less compensation for risk than formal urban residents because they have fewer job alternatives. Unfortunately, few surveys in China include migrants since most surveys sample using the registration list.

\subsection{Risk Data}

The only publicly reported occupational-risk data in China are reported in China's Work Safety Yearbook from 2000 to $2002 .^{2}$ For each of these years, we compute the sector-average occupational fatal- and nonfatal-injury risks by dividing the number of work-related deaths and serious injuries by the number of workers, respectively. The time-averaged fatality and serious-injury rates are reported in Table 2.

Chinese statistics on occupational injuries are often viewed as underestimates because of suspected under-reporting by employers. The industry-average reported fatality rate of 1.19 per 10,000 workers (Table 2) is comparable to reported injury rates in economies with much higher incomes, e.g., average rates per 10,000 of 1.04 from 1992 to 1998 in Hong Kong ${ }^{3}$ and falling from 3.83 in 1982 to 2.25 in 1986 in Taiwan (Liu et al. 1997). Whether or not the level is accurate, the ranking of sectors by risk appears reasonable, with "mining and quarrying," "others," and "construction" showing the largest fatal risks (Table 2). In the US, the ranking of industries by fatal risk (from high to low) is "Mining," "Agriculture, Forestry and Fisheries," "Construction," "Transportation and Utilities," "Manufacturing," "Wholesale Trade," "Retail Trade," "Services" and "Finance, Insurance and Real Estate" (1992-1995 average; Viscusi and Aldy 2003). In Hong Kong, "Mining," "Construction," and "Transportation, Storage and Communications" are the three most dangerous industries (1994-2000 average; National Bureau of Statistics 2003).

\footnotetext{
2 State Administration of Work Safety and State Administration of Coal Mine Industry (2000-2002). Data for years before 2000 are not published.

3 Computed from data in National Bureau of Statistics (2003).
} 
Table 1 Variable definition and statistics

\begin{tabular}{|c|c|c|c|c|}
\hline \multirow[t]{2}{*}{ Variable } & \multirow[t]{2}{*}{ Definition } & \multicolumn{3}{|c|}{ Mean (Standard deviation) } \\
\hline & & Full sample & Skilled workers & Unskilled workers \\
\hline ANNUALW & Annual wage (yuan) & $5973.78(3323.19)$ & $5655.67(2950.57)$ & $4876.95(2740.73)$ \\
\hline AGE & Age & $38.68(9.41)$ & $37.24(9.13)$ & $36.46(8.77)$ \\
\hline GENDER & 1 if male, 0 if female & $0.53(0.50)$ & $0.62(0.49)$ & $0.38(0.49)$ \\
\hline MARRIAGE & $\begin{array}{l}1 \text { if currently married; } 0 \\
\text { otherwise }\end{array}$ & $0.88(0.32)$ & $0.83(0.37)$ & $0.85(0.36)$ \\
\hline PARTY & $\begin{array}{l}1 \text { if communist party } \\
\text { member, } 0 \text { otherwise }\end{array}$ & $0.26(0.44)$ & $0.12(0.32)$ & $0.072(0.26)$ \\
\hline EDUY & $\begin{array}{l}\text { Number of years of } \\
\text { education received }\end{array}$ & $10.88(2.90)$ & $9.67(2.36)$ & $9.00(2.19)$ \\
\hline EXP & $\begin{array}{l}\text { Number of years of } \\
\text { working experience }\end{array}$ & $19.58(9.51)$ & 18.74(9.26) & 16.91(8.66) \\
\hline UNDERGW & $\begin{array}{l}1 \text { if working environment is } \\
\text { under ground or under } \\
\text { water, } 0 \text { otherwise }\end{array}$ & $0.0037(0.06)$ & $0.0077(0.09)$ & $0.011(0.10)$ \\
\hline TEMPER & $\begin{array}{l}1 \text { if work under high or low } \\
\text { temperature, } 0 \text { otherwise }\end{array}$ & $0.047(0.211)$ & $0.12(0.33)$ & $0.072(0.26)$ \\
\hline TOXIC & $\begin{array}{l}1 \text { if the worker works in a } \\
\text { toxic environment or } \\
\text { other dangerous situation; } \\
0 \text { otherwise }\end{array}$ & $0.065(0.246)$ & $0.17(0.38)$ & $0.068(0.25)$ \\
\hline DAY & $\begin{array}{l}\text { Average number of work } \\
\text { days per week in } 1995\end{array}$ & $5.45(0.61)$ & $5.54(0.62)$ & $5.63(0.68)$ \\
\hline INTENSIVE & $\begin{array}{l}\text { Intensiveness of work: } 1 \text {, } \\
\text { not intensive; } 2 \text { moderate; } \\
3 \text { very intensive }\end{array}$ & $2.04(0.43)$ & $2.14(0.45)$ & $2.04(0.42)$ \\
\hline DISSAT & $\begin{array}{l}\text { Satisfaction of work } \\
\text { environment: from 1-very } \\
\text { satisfied to 5-very } \\
\text { dissatisfied }\end{array}$ & $2.67(0.84)$ & $2.90(0.82)$ & $2.89(0.81)$ \\
\hline OWNER & $\begin{array}{l}1 \text { if the worker is owner or } \\
\text { manager of private or } \\
\text { individual enterprise; } 0 \\
\text { otherwise }\end{array}$ & $0.0064(0.080)$ & N.A. & N.A. \\
\hline HEAD & $\begin{array}{l}1 \text { if the worker is head of } \\
\text { institution }\end{array}$ & $0.12(0.33)$ & N.A. & N.A. \\
\hline PROF & $\begin{array}{l}1 \text { if the worker is } \\
\text { professional or technical } \\
\text { worker }\end{array}$ & $0.24(0.41)$ & N.A. & N.A. \\
\hline OFFICE & $\begin{array}{l}1 \text { if the worker is office } \\
\text { worker }\end{array}$ & $0.22(0.41)$ & N.A. & N.A. \\
\hline SKILLED & $\begin{array}{l}1 \text { if the worker is skilled } \\
\text { worker }\end{array}$ & $0.21(0.41)$ & N.A. & N.A. \\
\hline UNSKILLED & $\begin{array}{l}1 \text { if the worker is unskilled } \\
\text { worker }\end{array}$ & $0.15(0.36)$ & N.A. & N.A. \\
\hline PERMANENT & $\begin{array}{l}1 \text { if the worker is permanent } \\
\text { worker }\end{array}$ & $0.79(0.41)$ & $0.67(0.47)$ & $0.63(0.48)$ \\
\hline LONGTERM & $\begin{array}{l}1 \text { if the worker is long-term } \\
\text { contract worker }\end{array}$ & $0.18(0.39)$ & $0.30(0.46)$ & $0.32(0.46)$ \\
\hline TEMPORARY & $\begin{array}{l}1 \text { if the worker is temporary } \\
\text { worker }\end{array}$ & $0.022(0.15)$ & $0.024(0.15)$ & $0.055(0.23)$ \\
\hline
\end{tabular}


Table 1 continued

\begin{tabular}{|c|c|c|c|c|}
\hline \multirow[t]{2}{*}{ Variable } & \multirow[t]{2}{*}{ Definition } & \multicolumn{3}{|c|}{ Mean (Standard deviation) } \\
\hline & & Full sample & Skilled workers & Unskilled workers \\
\hline PUBLIC & $\begin{array}{l}1 \text { if workplace is } \\
\text { state-owned or local } \\
\text { publicly-owned, } 0 \\
\text { otherwise }\end{array}$ & $0.84(0.37)$ & $0.81(0.39)$ & $0.70(0.46)$ \\
\hline INDIVIDUAL & $\begin{array}{l}1 \text { if workplace is } \\
\text { self-employed } \\
\text { business/individual } \\
\text { enterprise, } 0 \text { otherwise }\end{array}$ & $0.001(0.033)$ & 0 & 0 \\
\hline COLLECTIVE & $\begin{array}{l}1 \text { if workplace is urban } \\
\text { collective, } 0 \text { otherwise }\end{array}$ & $0.14(0.35)$ & $0.17(0.37)$ & $0.28(0.45)$ \\
\hline SINOFOR & $\begin{array}{l}1 \text { if workplace is } \\
\text { sino-foreign joint venture, } \\
0 \text { otherwise }\end{array}$ & $0.011(0.11)$ & $0.019(0.14)$ & $0.013(0.11)$ \\
\hline FOREIGN & $\begin{array}{l}1 \text { if workplace is foreign } \\
\text { owned, } 0 \text { otherwise }\end{array}$ & $0.001(0.033)$ & $0.0005(0.022)$ & $0.0027(0.052)$ \\
\hline HEAPUB & $\begin{array}{l}1 \text { if public health service } \\
\text { provided by the state of } \\
\text { the working unit is } \\
\text { received by workers; } 0 \\
\text { otherwise }\end{array}$ & $0.69(0.46)$ & $0.71(0.45)$ & $0.58(0.49)$ \\
\hline HEASELF & $\begin{array}{l}1 \text { if health protection of } \\
\text { workers is entirely } \\
\text { self-employed; } 0 \\
\text { otherwise }\end{array}$ & $0.13(0.33)$ & $0.12(0.32)$ & $0.20(0.40)$ \\
\hline LOSE & $\begin{array}{l}1 \text { if the worker reports that } \\
\text { his working place is } \\
\text { losing money; } 0 \text { otherwise }\end{array}$ & $0.20(0.40)$ & $0.29(0.45)$ & $0.25(0.44)$ \\
\hline UNEM & $\begin{array}{l}\text { Adjusted urban } \\
\text { unemployment rate }\end{array}$ & $0.057(0.023)$ & $0.056(0.024)$ & $0.054(0.020)$ \\
\hline DR1 & $\begin{array}{l}\text { Sector fatality rate per } \\
10,000 \text { workers }\end{array}$ & $0.61(1.51)$ & $0.78(1.35)$ & $0.76(1.57)$ \\
\hline $\mathrm{N}$ & Number of observations & 10,165 & 2,100 & 1,524 \\
\hline
\end{tabular}

Source: Computed from urban individual data set of Chinese Household Income Project 1995 (Riskin et al. 2000), ICPSR 3012

We estimate risks to each worker in our sample by matching the economic sector of employment with the most similar sector for which we have risk estimates. There are two concerns with this matching. First, our data on workers and occupational risks date from different periods (1995 and 2000-2002, respectively). Annual risk estimates by industry suggest a rising trend, with average-industry fatality risk increasing $12 \%$ from 2000 to 2001 and $17 \%$ from 2001 to 2002. The estimated annual risk increases in both years for 10 of 16 industries. Whether this short-term trend reflects an increase in risk or a decrease in under-reporting of deaths is unknown, but we suspect that it reflects less under-reporting, given that average risks are small compared with other economies. Second, there are modest differences between some of the economic sectors included in the two data sets. We matched workers from the 13 sectors of the worker-survey data to the 16 sectors of the risk data as reported in Table 3 . In cases of doubt (e.g. workers in SEC7, "Real estate, public utilities, personal and consulting services") we tested other reasonable matches and found that our overall conclusions are not affected. 
Table 2 Workplace fatality and serious-injury rates (per 10,000 workers, 2000-2002 average)

\begin{tabular}{llrl}
\hline & Sector & Fatality & Serious injury \\
\hline 1 & Agriculture, Hunting, Forestry and Fishing & 0.213 & 0.150 \\
2 & Mining and Quarrying & 13.815 & 1.154 \\
3 & Manufacturing & 0.721 & 0.691 \\
4 & Production and Supply of Electricity, Gas and Water & 0.868 & 0.261 \\
5 & Construction & 2.234 & 0.643 \\
6 & Geological Prospecting and Water Conservancy & 0.389 & 0.153 \\
7 & Transport, Storage, Post and Telecommunication & 0.336 & 0.317 \\
8 & Wholesale and Retail Trade and Catering Services & 0.225 & 0.074 \\
9 & Finance and Insurance & 0.006 & 0.003 \\
10 & Real Estate Trade & 0.267 & 0.110 \\
11 & Social Services & 0.355 & 0.130 \\
12 & Health Care, Sporting and Social Welfare & 0.010 & 0.008 \\
13 & Education, Culture and Arts, Radio, Film and Television & 0.016 & 0.008 \\
14 & Scientific Research and Poly-technical Services & 0.083 & 0.063 \\
15 & Government Agencies, Party Agencies and Social Organizations & 0.015 & 0.005 \\
16 & Others & 3.365 & 2.127 \\
& Total & 1.188 & 0.365
\end{tabular}

Source: Computed using data from National Bureau of Statistics (2003) and State Administration of Work Safety and State Administration of Coal Mine Industry (2000-2002)

Due to data limitations, we follow many other studies of compensating wage differentials by using industry-average estimates that assume all workers in an industry face the same risk (Viscusi and Aldy 2003). ${ }^{4}$ Clearly, risk varies within industries; e.g., a collier faces higher risk than an accountant working at the same mine. Indeed, most of the occupational fatalities and injuries may occur among workers in the higher-risk jobs in an industry. Viscusi (2004) finds that risk within US industry is strongly associated with occupation. Averaging across industries, occupational fatality risk is smaller than average for eight of ten major occupations; workers in the two remaining occupations face risks three and five times larger than average. Within the nine industrial sectors he considers, fatal risk of the riskiest occupation ranges from 1.8 to 9.0 times the industry average.

When risk is heterogeneous within industry, industry-average risk may be informative about the risks faced by high-risk workers but provide little information about risks to others. A standard approach to this problem is to restrict the sample to workers anticipated to be at relatively high risk (e.g., blue-collar workers). We follow this approach by estimating wage-risk models using alternatively the full sample, the subsample of skilled and unskilled workers, and the subsample of unskilled workers. Moreover, if only a subset of workers face significant occupational fatality risk, dividing occupational fatalities by total employment will underestimate occupational risk for that subset and bias upward the estimated coefficient on risk (Viscusi 2004). We test for the potential magnitude of this bias using alternative

4 We also follow previous studies in using risk estimates that do not vary by worker's age, as our risk data do not report age of workers killed or injured on the job. Viscusi and Aldy (2007) show that risk of fatal and nonfatal accidents in US industry vary by age and that failing to control for this variation may bias estimates of the age profile of VSL. Lacking data on risk by age, we do not investigate how risk compensation varies with age in China. 
Table 3 Distribution of workers by sector

\begin{tabular}{|c|c|c|c|}
\hline Dummy variable & Sector & Percentage & Matched to sector in Table 2 \\
\hline SEC1 & $\begin{array}{l}\text { Agricultural, forestry, animal } \\
\text { husbandry, fishing or water } \\
\text { conservancy }\end{array}$ & 1.65 & Sector 1 \\
\hline SEC2 & Manufacturing & 40.00 & Sector 3 \\
\hline SEC3 & $\begin{array}{l}\text { Mining and Geological Survey } \\
\text { and Prospecting }\end{array}$ & 1.14 & Sector 2 \\
\hline SEC4 & Construction & 3.01 & Sector 5 \\
\hline SEC5 & $\begin{array}{l}\text { Transportation, } \\
\text { Communications, Posts and } \\
\text { Telecommunications }\end{array}$ & 5.10 & Sector 7 \\
\hline SEC6 & $\begin{array}{l}\text { Commerce and Trade, } \\
\text { Restaurants and Catering, } \\
\text { Materials Supply, Marketing, } \\
\text { and Warehousing }\end{array}$ & 14.15 & Sector 8 \\
\hline SEC7 & $\begin{array}{l}\text { Real Estate, Public Utilities, } \\
\text { Personal and Consulting } \\
\text { Services }\end{array}$ & 3.81 & Weighted average of 10 and 11 \\
\hline SEC8 & $\begin{array}{l}\text { Health, Physical Cultural and } \\
\text { Social Welfare }\end{array}$ & 4.92 & Sector 12 \\
\hline SEC9 & $\begin{array}{l}\text { Education, Cultural, Arts and } \\
\text { Broadcasting }\end{array}$ & 8.05 & Sector 13 \\
\hline SEC10 & $\begin{array}{l}\text { Scientific Research and } \\
\text { Technical Services }\end{array}$ & 2.59 & Sector 14 \\
\hline SEC11 & Finance, Insurance & 2.13 & Sector 9 \\
\hline SEC12 & $\begin{array}{l}\text { Government and Party Organs, } \\
\text { Social Organizations }\end{array}$ & 12.91 & Sector 15 \\
\hline SEC13 & Others & 0.66 & Sector 16 \\
\hline
\end{tabular}

estimates of industry risk based on the assumption that all fatalities occur to high-risk workers (defined alternatively as skilled and unskilled, or unskilled only). These innovative estimates are obtained by dividing the numbers of deaths in each sector by the number of high-risk workers in the sector (equivalently, by dividing the industry-average risks by the ratio of high-risk to total employment in the sector). To the extent that this adjustment overestimates the risk faced by low-skill workers, the estimated coefficient on risk will be biased downward. Hence the results using the conventional and alternative risk measures may bound the true relationship.

The distribution of workers by sector and occupation is reported in Table 4. Skilled and unskilled workers account for more than $30 \%$ of employees in six of 13 sectors. The original (industry-average) and alternative risk estimates are reported in Table 5. For sectors 1-7, skilled and unskilled workers account for at least one quarter of employment and so the estimate assuming only skilled and unskilled workers are at risk (DR2) is no more than four times as large as the industry-average risk (DR1). For some other sectors (e.g., 11, Finance and Insurance; 12 Government and party organs, social organizations), skilled and unskilled workers account for fewer than $10 \%$ of employment and so the alternative risk estimates are more than ten times as large as the conventional estimates and seem implausibly large. The average (employment-weighted) value of the alternative risk estimate assuming skilled and unskilled workers are at risk (DR2) is less than three times larger than the average workplace fatality risk. 
Table 4 Distribution of workers by occupation and sector (percent)

\begin{tabular}{lrllrrrrr}
\hline Sector & \multicolumn{1}{c}{$\mathrm{N}$} & Owner & Professional & Head & Office & Skilled & Unskilled & Other \\
\hline 1 & 165 & 1.21 & 32.12 & 18.79 & 20.61 & 13.94 & 12.12 & 1.21 \\
2 & 3,956 & 0.58 & 17.69 & 7.13 & 13.14 & 36.83 & 22.30 & 2.33 \\
3 & 112 & 1.79 & 31.25 & 10.71 & 16.07 & 17.86 & 17.86 & 4.46 \\
4 & 296 & 0.34 & 27.03 & 8.45 & 17.57 & 29.05 & 14.19 & 3.37 \\
5 & 513 & 0.58 & 19.49 & 11.50 & 22.42 & 27.68 & 14.42 & 3.91 \\
6 & 1,394 & 0.65 & 11.98 & 11.69 & 29.34 & 10.40 & 22.31 & 13.63 \\
7 & 372 & 0.54 & 16.40 & 11.56 & 26.88 & 16.67 & 18.82 & 9.13 \\
8 & 490 & 0 & 59.39 & 8.98 & 15.51 & 8.16 & 4.90 & 3.06 \\
9 & 806 & 0.37 & 57.20 & 12.66 & 16.25 & 4.59 & 3.97 & 4.96 \\
10 & 261 & 1.15 & 59.39 & 15.71 & 9.58 & 10.73 & 2.30 & 1.14 \\
11 & 211 & 0.95 & 26.54 & 14.22 & 50.24 & 4.27 & 1.90 & 1.88 \\
12 & 1,295 & 1.00 & 16.22 & 30.58 & 44.40 & 3.86 & 2.24 & 1.7 \\
13 & 65 & 1.54 & 20.00 & 16.92 & 29.23 & 7.69 & 15.38 & 9.24 \\
\hline
\end{tabular}

Source: Computed from urban individual data set of Chinese Household Income Project 1995 (Riskin et al. 2000), ICPSR 3012

Table 5 Original and alternative fatality risks (deaths per 10,000 workers)

\begin{tabular}{lccc}
\hline Sector & $\begin{array}{l}\text { All workers } \\
\text { (DR1) }\end{array}$ & $\begin{array}{l}\text { Skilled and unskilled } \\
\text { workers (DR2) }\end{array}$ & $\begin{array}{l}\text { Unskilled workers } \\
\text { (DR3) }\end{array}$ \\
\hline 1 & 0.213 & 0.814 & 1.743 \\
2 & 0.721 & 1.219 & 3.233 \\
3 & 13.815 & 38.676 & 77.352 \\
4 & 2.234 & 5.168 & 15.747 \\
5 & 0.336 & 0.798 & 2.331 \\
6 & 0.225 & 0.689 & 1.010 \\
7 & 0.339 & 0.956 & 1.803 \\
8 & 0.0104 & 0.08 & 0.213 \\
9 & 0.0156 & 0.183 & 0.394 \\
10 & 0.0835 & 0.641 & 3.629 \\
11 & 0.00570 & 0.092 & 0.300 \\
12 & 0.0150 & 0.245 & 0.668 \\
13 & 3.365 & 14.586 & 21.879 \\
Sample mean (std. dev.) & $0.61(1.51)$ & $1.65(4.09)$ & $3.93(8.94)$ \\
\hline
\end{tabular}

Note: Sample mean and standard deviation are employment weighted

\subsection{Local Unemployment}

To examine the effects of unemployment on compensation for occupational risk, we include in the model an adjusted province-level measure of urban unemployment. Chinese unemployment statistics are based on the number of individuals who register for unemployment benefits with local governments and not on representative sample surveys (Giles et al. 2005). The official unemployment rates are believed to significantly understate true unemployment 
as they exclude workers laid off with no expectation of reemployment, who lost jobs but did not register with local government, and who involuntarily retired early, among others. An offsetting bias exists because substantial numbers of officially registered unemployed workers may be working or no longer looking for work (Giles et al. 2005).

The National Bureau of Statistics reports the official national unemployment rate as $2.9 \%$ in 1995. Giles et al. (2005) estimate the "true" unemployment rate from 1996 to 2001 in five large cities using a 2002 unemployment survey that applied internationally standard definitions of unemployment. ${ }^{5}$ They estimate the unemployment rate among urban permanent residents (excluding migrants) as 6.1\% in January 1996.

We adjust the official province-level urban unemployment rates by assuming that official unemployment rates underestimate true unemployment by a constant factor. Thus we inflate the official province-level unemployment rates in 1995 (National Bureau of Statistics 1996) by the ratio of Giles's estimate (0.061) to the official national rate (0.029), i.e., by a factor of 2.1 (for comparison, the ratios of Giles's estimates for each of five cities to the corresponding official estimates range between 3.4 and 5.8). This yields an adjusted sample-average unemployment rate of 5.7 percent (Table 1).

\section{Results}

We estimate Eq. 1 in semi-logarithmic form using the natural logarithm of wage as the dependent variable and including fatal- and nonfatal-injury rates individually and jointly. The estimated coefficient of the nonfatal-injury rate is never statistically significant, perhaps because of an errors-in-variables bias due to poor quality data. Although workers are expected to receive compensation for both fatal- and nonfatal-injury risks, many studies have been unable to econometrically identify both effects (Viscusi and Aldy 2003). Following common practice, we report estimates using models that include only fatal-risk variables.

\subsection{Regressions Without Unemployment Interactions}

Estimates of the standard wage-risk equation (i.e., without unemployment-risk interaction terms) are reported in Table 6. Models are estimated for the full sample (Models I and II), and for the subsamples of skilled and unskilled workers jointly (Models III and IV) and separately (Models V and VI). The paired models estimated using the same sample (i.e., Models I and II, Models III and IV) differ only in the inclusion of an interaction between occupational risk and unskilled workers (DR1 $\times$ UNSKILL).

The estimated coefficients of the human-capital and job-characteristic variables are similar across all six models. As an example, consider Model I estimated for the full sample. Work experience has a positive but diminishing effect on the log of annual wages. At the sample mean, an additional year of experience is associated with a $1.5 \%$ higher wage. Similarly, an additional year of education is associated with $1.9 \%$ higher wages. Men earn about $6.5 \%$ more than women, ${ }^{6}$ married workers earn about $10.3 \%$ more than unmarried workers, and Communist party members earn about $3.3 \%$ more than non-members.

The estimated coefficients of TEMPER, TOXIC and UNDERGW are all positive, implying that workers are compensated for exposure to harsher working environments. The estimated

\footnotetext{
${ }^{5}$ Unemployment is generally defined to include individuals who are not working, able to work, and looking for work during the defined reference period (Giles et al. 2005).

$6 \exp (0.063)-1=0.065$.
} 


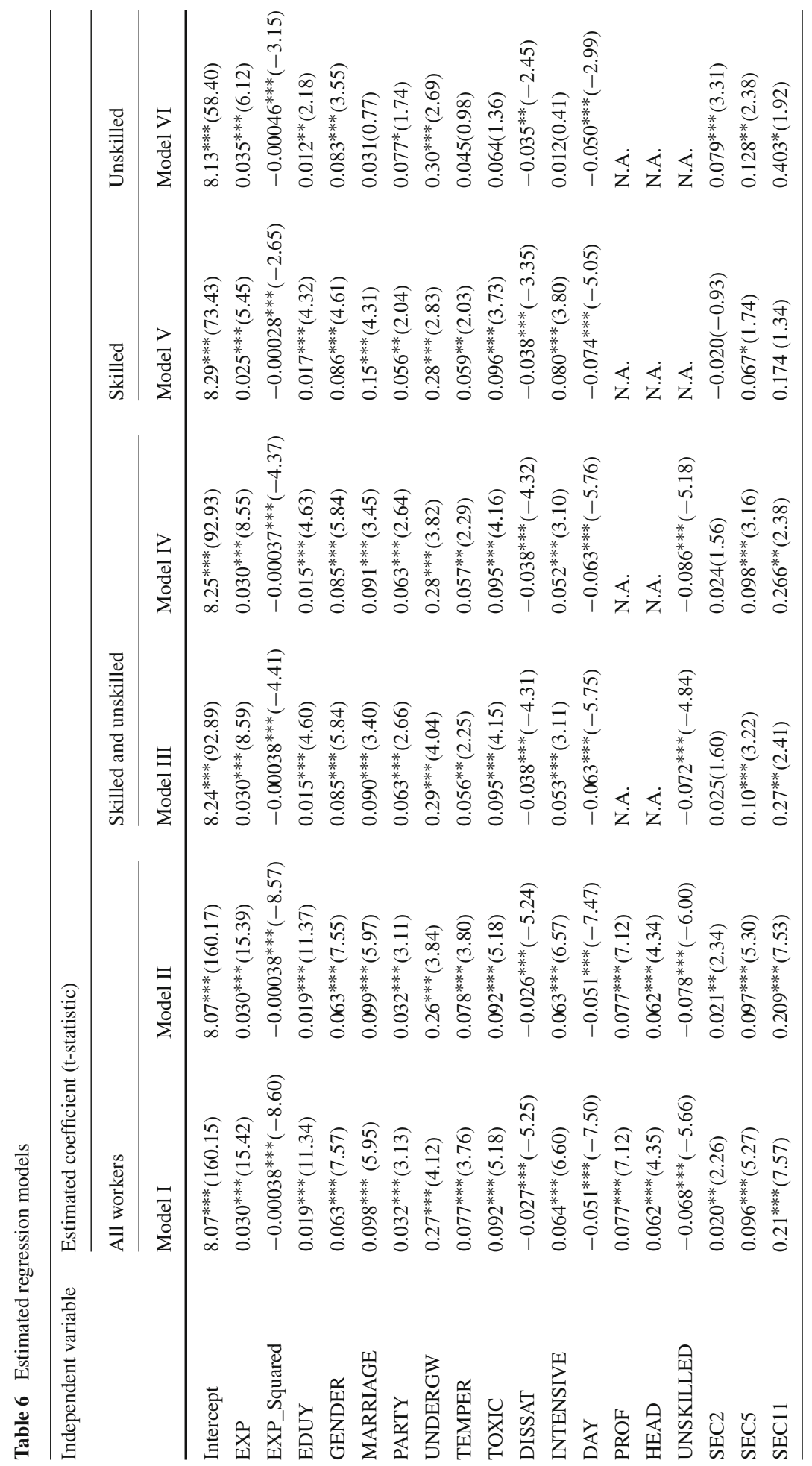




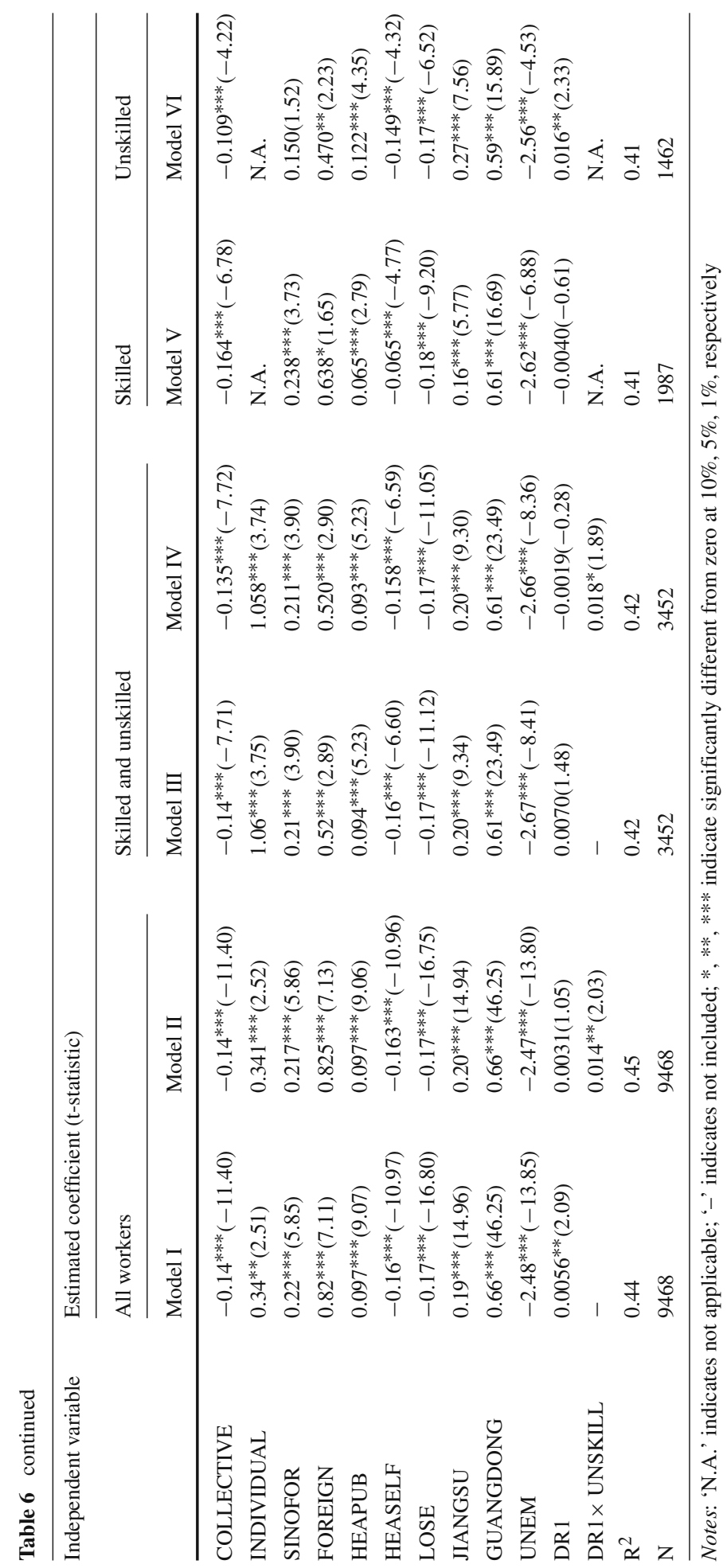


coefficient of DISSAT is negative, implying that less satisfied workers receive lower wages (possibly reflecting reverse causality). INTENSIVE has a positive coefficient, meaning that workers who think their jobs are more intensive than average earn higher wages. DAY (average days worked per year) has a negative coefficient, perhaps because jobs requiring more working days per week are often low-paid labor jobs (the mean value of DAY is larger for unskilled workers than for the full sample, Table 1). The estimated coefficients of PROF, HEAD and UNSKILLED show that professional workers and technical workers earn about $8.0 \%$ more, heads of institutions earn about $6.4 \%$ more, and unskilled workers earn about $7.0 \%$ less than the omitted categories (owners, office and skilled workers).

Three economic sectors show significantly larger wages than others: manufacturing (SEC2), 2.0\%; transportation, communications, posts and telecommunications (SEC5), 10\%; and finance and insurance (SEC11), 23\%. Workplace ownership is associated with significant differences in wages: individually owned, 40 percent more; Sino-foreign joint-ventures, $25 \%$ more; foreign owned, $130 \%$ more; and urban-collective enterprises, 13 percent less.

HEAPUB and HEASELF are variables characterizing workers' health care. Workers with state or work-unit provided health care earn 10 percent more and workers who self-finance their health care earn 15 percent less than others. These results suggest that differences in total compensation are larger than revealed by the distribution of wages, as more-highly-paid jobs are more likely to provide some form of health insurance. Workers employed by enterprises that lost money in 1995 earn 16\% less. Workers in the coastal provinces that enjoyed the highest economic growth during the reform period, Jiangsu and Guangdong, earn 21\% more and $93 \%$ more, respectively, than workers in other provinces (controlling for other factors in the model).

As anticipated, workers in provinces with higher unemployment rates earn lower wages. The estimated effect of province-level unemployment depends on which province-level indicator variables are included in the model but estimates are generally negative and significant. Substituting a binary variable to distinguish provinces with relatively high- and low-unemployment for the provincial rate also yields a negative and significant effect of unemployment for a range of thresholds. For our preferred specification (Model I), a 1\% point increase in unemployment is associated with a $2.5 \%$ wage decrease. ${ }^{7}$

In Model I, the estimated coefficient of industry-average fatality risk (DR1) is statistically significant and positive, supporting the hypothesis that workers receive higher wages to compensate for greater occupational risk. Note that the possibility of confounding compensation for risk with other sources of between-industry wage differences (Leigh 1995) is partially controlled by including indicator variables for the sectors with significantly different wages (SEC2, SEC5, and SEC11). Indeed, when Model I is re-estimated without these sector variables the estimated coefficient on mortality risk falls (from 0.0056 to 0.0042 ) and we cannot reject the hypothesis that the coefficient is zero (the p-value increases from 0.04 to 0.12 ). ${ }^{8}$

Comparison among the models reported in Table 6 suggests that the wage differential is most apparent for unskilled workers. Model II is identical to Model I except it includes an interaction between occupational risk and the indicator variable for unskilled workers. Adding this interaction reduces the estimated coefficient of fatality risk by almost half (from 0.0056 to 0.0031 ) and renders it statistically insignificantly different from zero. The estimated

\footnotetext{
7 As described above, we multiplied the official unemployment rate by 2.1 to account for apparent undercount. Using the official measure, the estimated coefficient would be a factor of 2.1 larger than reported in Table 6 and the estimated effect of a $1 \%$ increase in unemployment would be to reduce wages by $5.2 \%$.

8 Omitting the three sector variables has little effect on any of the other coefficients or models in Tables 6 and 7 with the exception of Model VIII (Table 7) where excluding these variables reduces the estimated coefficient on mortality risk (from 0.062 to 0.054 ) and increases the p-value (from 0.09 to 0.14 ).
} 
coefficient of the interaction term (0.014) is 2.5 times larger than the fatal-risk coefficient in Model I and significantly different from zero at the $5 \%$ level. Estimates of the same wage-risk equations ${ }^{9}$ on the subsample of skilled and unskilled workers (Models III and IV) and on the subsamples of skilled (Model V) and unskilled (Model VI) workers alone yield essentially the same result: a positive and significant coefficient on fatal risk for unskilled workers (the main effect or main effect plus interaction ranges between 0.016 and 0.017 in Models II, IV, and VI), and no significant coefficient on fatal risk for other workers.

The insignificant coefficients on risk for skilled workers do not imply that such workers receive no compensation for occupational risk; only that it is not detected using our data. The apparent differences in the coefficients on risk between unskilled and other workers suggest that pooled estimates (e.g., Models I and III) are biased and the estimate from the unskilledworkers subsample (Model VI) may be more consistent (for the population of unskilled workers). The estimated coefficient of 0.016 implies that an increase in annual fatality risk of one per 10,000 is associated with a $1.6 \%$ increase in wages.

\subsection{Compensating Wage Differentials with Unemployment Interactions}

We examine the effect of unemployment on compensation for occupational risk by including interaction terms between fatal occupational risk and province-level unemployment and unemployment squared. Estimates of the wage-risk equation for the full sample and the unskilled-worker subsample are reported in Table 7 and are similar to those reported in Table 6 . The estimated effect of unemployment on wages remains negative and statistically significant, though slightly smaller in absolute value when the risk-unemployment interaction terms are included.

In the full-sample estimate (Model VII), the coefficients of the risk-unemployment interactions are significantly different from zero at the $1 \%$ level. The negative coefficient of the interaction with unemployment and positive coefficient of the interaction with unemployment squared imply that compensation for occupational risk decreases at a decreasing rate with unemployment, reaching a minimum at $8.1 \%$ unemployment. The estimated compensation for risk ranges from $5.5 \%$ for a 1 per 10,000 risk increment with no unemployment to approximately zero $(-0.07 \%)$ with $8.1 \%$ unemployment. In the unskilled-worker subsample (Model VIII), the estimated coefficients of the two interaction terms are similar to their values in the full sample but are not statistically significantly different from zero, perhaps because of the smaller sample. ${ }^{10}$

We also find that unemployment suppresses compensation for some of the other undesirable job characteristics represented by the variables UNDERGW, TEMPER, TOXIC, and INTENSIVE. We supplement Models VII and VIII with interactions between each of these variables and unemployment (results not shown). For the full sample (Model VII), the estimated coefficients of the interactions with UNDERGW and INTENSIVE are negative and statistically significant at the $1 \%$ level. In the unskilled-worker subsample (Model VIII), the coefficient of the interaction with UNDERGW is negative and significant at the $5 \%$ level. In both models, the corresponding main effects increase in absolute value but the estimated coefficients of other variables are not significantly affected.

These results suggest that the hedonic wage function $w(p)$ shifts downward and becomes flatter as unemployment increases. The downward shift may be explained by a surplus of

\footnotetext{
9 Occupational indicator variables are dropped as appropriate.

10 For Model VIII, the wage differential for a 1 per 10,000 risk increment is estimated to decrease from $6.2 \%$ with no unemployment to a minimum of $0.4 \%$ at $7.1 \%$ unemployment.
} 
Table 7 Estimated regression models including risk-unemployment rate interaction
Notes: *,**, *** indicate significantly different from zero at $10 \%, 5 \%, 1 \%$, respectively

\begin{tabular}{|c|c|c|}
\hline \multirow[t]{2}{*}{ Independent variable } & \multicolumn{2}{|c|}{ Estimated coefficients (t-statistic) } \\
\hline & $\begin{array}{l}\text { All workers } \\
\text { Model VII }\end{array}$ & $\begin{array}{l}\text { Unskilled } \\
\text { Model VIII }\end{array}$ \\
\hline Intercept & $8.05^{* * *}(159.26)$ & $8.11^{* * *}(57.74)$ \\
\hline EXP & $0.030^{* * *}(15.47)$ & $0.034^{* * *}(6.11)$ \\
\hline EXP_Squared & $-0.00038(-8.65)^{* * *}$ & $-0.00046(-3.12) * * *$ \\
\hline EDUY & $0.019^{* * *}(11.39)$ & $0.012^{* *}(2.14)$ \\
\hline GENDER & $0.063^{* * *}(7.49)$ & $0.084^{* * *}(3.58)$ \\
\hline MARRIAGE & $0.098^{* * *}(5.94)$ & $0.030(0.74)$ \\
\hline PARTY & $0.032^{* * *}(3.11)$ & $0.075^{*}(1.69)$ \\
\hline UNDERGW & $0.26^{* * *}(3.94)$ & $0.30^{* * *}(2.68)$ \\
\hline TEMPER & $0.079^{* * *}(3.82)$ & $0.045(0.98)$ \\
\hline TOXIC & $0.093^{* * *}(5.25)$ & $0.069(1.46)$ \\
\hline DISSAT & $-0.027^{* * *}(-5.27)$ & $-0.036^{* *}(-2.46)$ \\
\hline INTENSIVE & $0.063^{* * *}(6.50)$ & $0.0090(0.32)$ \\
\hline DAY & $-0.050^{* * *}(-7.40)$ & $-0.048^{* * *}(-2.84)$ \\
\hline PROF & $0.077^{* * *}(7.17)$ & N.A. \\
\hline HEAD & $0.062^{* * *}(4.37)$ & N.A. \\
\hline UNSKILLED & $-0.069^{* * *}(-5.77)$ & N.A. \\
\hline SEC2 & $0.020^{* *}(2.18)$ & $0.081^{* * *}(3.37)$ \\
\hline SEC5 & $0.096^{* * *}(5.29)$ & $0.128^{* *}(2.38)$ \\
\hline SEC11 & $0.21^{* * *}(7.59)$ & $0.40 *(1.91)$ \\
\hline COLLECTIVE & $-0.14^{* * *}(-11.38)$ & $-0.11^{* * *}(-4.17)$ \\
\hline INDIVIDUAL & $0.34^{* *}(2.51)$ & N.A. \\
\hline SINOFOR & $0.22^{* * *}(5.87)$ & $0.15(1.53)$ \\
\hline FOREIGN & $0.80^{* * *}(6.93)$ & $0.47^{* *}(2.23)$ \\
\hline HEAPUB & $0.097^{* * *}(9.07)$ & $0.12^{* * *}(4.29)$ \\
\hline HEASELF & $-0.16^{* * *}(-10.93)$ & $-0.15^{* * *}(-4.39)$ \\
\hline LOSE & $-0.17^{* * *}(-16.77)$ & $-0.17^{* * *}(-6.48)$ \\
\hline JIANGSU & $0.20^{* * *}(15.04)$ & $0.28^{* * *}(7.62)$ \\
\hline GUANGDONG & $0.67^{* * *}(46.38)$ & $0.60^{* * *}(15.95)$ \\
\hline UNEM & $-2.29^{* * *}(-11.84)$ & $-2.34^{* * *}(-3.69)$ \\
\hline $\mathrm{DR} 1 \times \mathrm{UNEM}$ & $-1.37^{* * *}(-3.29)$ & $-1.63(-1.37)$ \\
\hline DR1 $\times$ UNEM_Sq & $8.43^{* * *}(2.99)$ & $11.49(1.43)$ \\
\hline DR1 & $0.055^{* * *}(3.68)$ & $0.062 *(1.70)$ \\
\hline $\mathrm{R}^{2}$ & 0.45 & 0.42 \\
\hline $\mathrm{N}$ & 9,468 & 1,462 \\
\hline
\end{tabular}

labor resulting in higher unemployment and lower price of labor. The flattening may be explained by workers' reluctance to quit a job, even if it offers inadequate compensation for occupational risk, when unemployment is high and the probability of finding a better job is low (Purse 2004). Alternatively, the flattening may be explained by a difference in workers' information about occupational risks. Suppose the surplus of labor supply is caused by an 
influx of new job seekers, such as migrants. ${ }^{11}$ Compared with more experienced workers, these new entrants may have less information about between-job differences in risks, may be less sensitive to these differences in choosing a job, and may demand less compensation to accept a higher-risk job.

Table 8 reports estimates of the wage-risk equation using the alternative fataloccupational-risk measures, constructed alternatively on the assumption that risks are concentrated among skilled and unskilled workers (DR2) or among unskilled workers (DR3) and estimated using the corresponding subsample. Estimated coefficients of the human-capital and job-characteristic variables are not reported but are similar to those reported in Tables 6 and 7. The pattern of estimated compensation for risk is similar to that observed using the industry-average risk DR1 in Tables 6 and 7. The absolute values of the coefficients are smaller than using DR1 because the average risks and between-industry risk differences are larger (Table 5). Some of the coefficients are not significantly different from zero. As with the sector-average risk measure, the estimated compensation for risk decreases convexly with unemployment.

\subsection{Value per Statistical Life}

The value per statistical life is the marginal rate of substitution between compensation and mortality risk. To compute it, we multiply the estimated marginal proportional effect of fatality risk on wages by the annual average wage and divide by the risk increment $(1 / 10,000) .{ }^{12}$ Estimates from our various models are summarized in Table $9 .{ }^{13}$

Using Model I (Table 6), the estimated full-sample VSL is about US\$45,000. Including the interaction term between risk and unskilled workers, the estimated VSL for the full sample excluding unskilled workers falls to US $\$ 25,000$ and the underlying coefficient is not statistically significantly different from zero (Model II). Estimates of VSL for the unskilled workers using their average wage (Table 1) and the full sample (Model II), the sample of skilled and unskilled workers (Model IV), or the sample of unskilled workers (Model VI) are all equal to US\$110,000.

Estimates from the models that include interactions between unemployment and occupational risk are somewhat smaller. At the corresponding sample-mean unemployment rate, estimated VSL is US $\$ 35,000$ for the full sample (Model VII) and US $\$ 50,000$ for the unskilledworker subsample (Model VIII). Estimates using the alternative risk measures that assume only skilled and unskilled, or only unskilled, workers are at risk are substantially smaller. For skilled and unskilled workers, VSL is estimated as US\$18,000 (Model IX, not significantly different from zero) and US\$7,200 (Model X) and for unskilled workers it is estimated as US $\$ 19,000$ (Model XI) and US\$13,000 (Model XII, not significant). The estimates using the alternative risk measures are much smaller than those using the sector-average risk measures because the alternative measures attribute the same between-sector differences in wages (controlling for worker and job characteristics) to larger between-sector differences in risk. The estimates based on the alternative risk estimates are more accurate measures of market

11 Unemployment among migrants is estimated to be less than among formal urban residents (Giles et al. 2005), perhaps because migrants from rural areas can return to their province of origin to work on farms if they cannot find a job in the cities.

12 For the full-sample estimate from Model I (Table 6), VSL $=[\exp (0.0056)-1] \times 5973.78 \times 10,000 / 8 \times$ 1.0848, where the last two factors convert from yuan to US\$ (8 yuan per US\$) and inflate from 1995 to 2000 US\$ using the US GDP deflator (1.0848).

13 Estimated VSL is not reported for cases where it would be less than zero, e.g., for skilled workers in Models IV and V. 


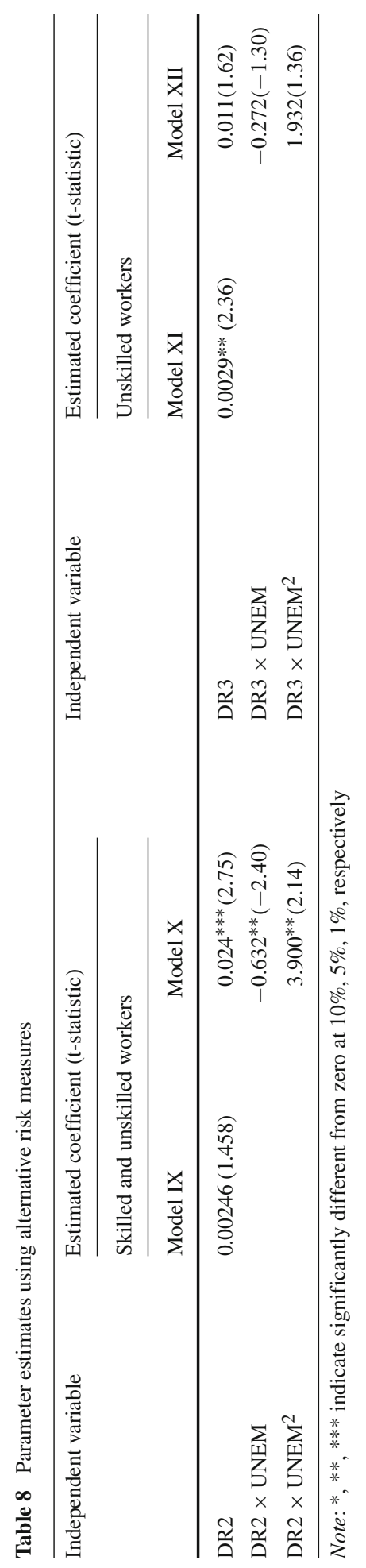


Table 9 Estimated value per statistical life (2000 US\$)

\begin{tabular}{|c|c|c|c|c|c|c|}
\hline & \multicolumn{2}{|c|}{ Full sample } & \multicolumn{2}{|c|}{ Unskilled workers } & \multicolumn{2}{|c|}{ Skilled and unskilled workers } \\
\hline & Model & VSL & Model & VSL & Model & VSL \\
\hline \multirow[t]{3}{*}{ Standard } & I & $45,000 * *$ & II & $110,000 * *$ & III & 51,000 \\
\hline & II & 25,000 & IV & $110,000 *$ & & \\
\hline & & & VI & $110,000 * *$ & & \\
\hline Interaction with unemployment & VII & $35,000 * * *$ & VIII & $50,000 *$ & & \\
\hline \multirow[t]{2}{*}{ Alternative risk measures } & & & XI & $19,000 * *$ & IX & 18,000 \\
\hline & & & XII & 13,000 & $X$ & $7,200 * *$ \\
\hline
\end{tabular}

Notes: $*, * *, * * *$ indicate significantly different from zero at $10 \%, 5 \%, 1 \%$, respectively. VSL estimated using mean wages for appropriate subsample, exchange rate of 8 yuan per US\$, and adjusted from 1995 to 2000 US\$ using US GDP deflator (1.0848)

compensation for risk if and only if occupational fatality risk is concentrated among the subsamples of unskilled and skilled workers, a hypothesis we cannot test with our data.

Our estimates are comparable to estimates of VSL in China from other studies. The World Bank (1997) reports a VSL of US\$60,000 in urban areas obtained by extrapolating from contingent valuation results in the US (details of the extrapolation are not provided). Direct estimates using the wage-differential method in other countries and using stated-preference methods in urban China are summarized in Table 10.

Using the conventional specification for all workers (Model I) and for the subsample of unskilled workers (Model VI), our estimates of VSL are 56 and 170 times the average labor earnings for the respective samples. Previous estimates of VSL from wage-differential studies in Hong Kong, Taiwan, South Korea, and Mexico yield comparable ratios (Table 10). Estimates for the United States yield ratios of VSL to average income that are substantially larger; e.g., Viscusi's (2004) estimates yield ratios of 320 and 370 for his full sample and blue-collar-male subsample. In contrast, our estimates of the fraction of the wage attributable to risk compensation $(0.3 \%$ and $1.3 \%)$ are smaller than the estimates for these other studies that range from about $1 \%$ to $7 \%$. Estimates of VSL for India are much larger in comparison with income and imply that $13-53 \%$ of the average wage is compensation for risk.

Two previous studies estimated VSL in urban China using stated-preference methods. These yield estimates of VSL in Beijing, Anqing, and Chongqing between US\$29,000 and US\$64,000, comparable to the estimates reported here, although the ratio of estimated VSL to income is smaller for the two estimates by Hammitt and Zhou (2006) (24 in Beijing, 17 in Anqing).

\section{Conclusion}

We find evidence of a statistically significant wage differential associated with betweenindustry differences in occupational-fatality risk. As a fraction of earnings, the estimated effect is significantly larger for unskilled workers than for other types of workers, possibly because between-industry differences in risk are larger for unskilled than for other workers. There is concern that occupational fatalities are under-reported, which could explain why reported occupational risks appear small compared with other economies; if risks are underestimated, our estimates of VSL would be biased upward. 


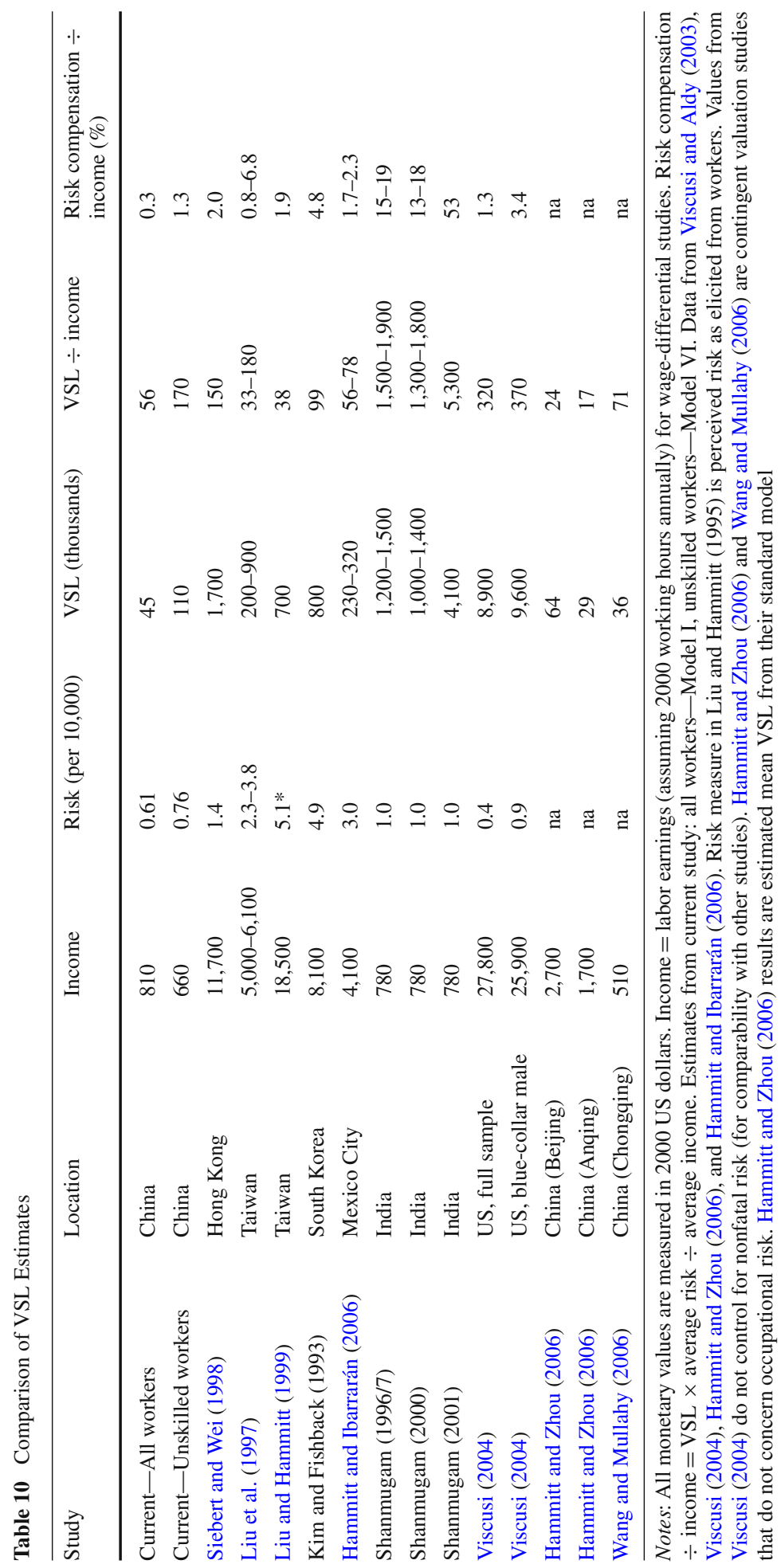


It is likely that a disproportionate share of the occupational risk within industries is born by less skilled workers. If so, the standard industry-average risk variable may underestimate the between-industry differences in risk faced by less skilled workers and overestimate the compensation per unit risk. Our alternative risk variables, which assume that only less skilled workers are exposed to occupational risk, are likely to overestimate the between-industry risk differences and underestimate the compensation per unit risk. Hence the estimates of VSL using the conventional risk measures (ranging from about US\$30,000 to US\$100,000) and those using the alternative risk measures (ranging from about US\$7,000 to US\$20,000) may bound the sample-average VSL.

We also find evidence that the compensating wage differential decreases (at a decreasing rate) with unemployment. The estimated effect is substantial: The estimated compensation for a 1 per 10,000 risk increment ranges from 5\% to $6 \%$ of wages with no unemployment to near zero with $7-8 \%$ unemployment (sample-mean unemployment is $5.7 \%$ ). The finding that unemployment suppresses the compensating wage differential implies that workers will accept not only lower wages, but also less incremental compensation for occupational risk, when unemployment is high. With high unemployment, workers who learn that a job is more dangerous than they anticipated may be reluctant to quit and so the perfect mobility assumption required for interpreting the compensating wage differential as a measure of workers' preferences for safety versus income may not be satisfied. Alternatively, the smaller rate of compensation may reflect a larger share of workers (e.g., new migrants) who are poorly informed about between-job differences in risk. The effect of unemployment on compensation for risk suggests that our estimates of VSL may be biased downward. To our knowledge, no previous studies have investigated this effect. If the effect exists in other countries, existing wage-differential estimates of VSL in those countries may also be biased downward.

Improved estimates of the value of reductions in mortality risk in China require better estimates of occupational risk, including information on how risk varies with occupation as well as industry. Data on occupational risk, workers' wages, human-capital, and other characteristics should correspond to a common time period. Further investigation of the effects of unemployment on compensation for risk requires more accurate estimates of unemployment rates by location and worker category.

Acknowledgements This study was supported by the Henry Luce Foundation, V. Kann Rasmussen Foundation, and Volvo Research and Educational Foundations as part of the China Project, Harvard University Center for the Environment and School of Engineering and Applied Sciences. We thank Joseph Aldy, Timothy Haab, Kip Viscusi, the editor, and two anonymous reviewers for their thoughtful comments.

\section{References}

Chestnut LG, Ostro BD, Vichit-Vadakan N (1997) Transferability of air pollution control health benefits estimates from the United States to developing countries: evidence from the Bangkok study. Am J Agric Econ 79:1630-1635. doi:10.2307/1244394

Dillingham EA, Smith RS (1984) Union effects on the valuation of fatal risk. In: Dennis BB (ed) Proceedings of the industrial relations research association 36th annual meeting, San Francisco, CA, December 28-30, 1983. Industrial Relations Research Association, Madison, pp 270-277

Dorman P (1996) Markets and mortality: economics, dangerous work and the value of human life. Cambridge University Press, Cambridge

Dorsey S (1983) Employment hazards and fringe benefits: further tests for compensating differentials. In: Worrall JD (ed) Safety and the workforce: incentives and disincentives in workers' compensation. ILR Press, Ithaca, pp 87-102

Giles J, Park A, Zhang J (2005) What is China's true unemployment rate? China Econ Rev 16:149-170. doi:10. 1016/j.chieco.2004.11.002 
Hammitt JK, Ibarrarán ME (2006) The economic value of reducing fatal and non-fatal occupational risks in Mexico City using actuarial- and perceived-risk estimates. Health Econ Lett 15:1329-1335. doi:10. 1002/hec.1137

Hammitt JK, Liu J-T (2004) Effects of disease type and latency on the value of mortality risk. J Risk Uncertain 28:73-95. doi:10.1023/B:RISK.0000009437.24783.e1

Hammitt JK, Zhou Y (2006) The economic value of air-pollution-related health risks in China: a contingent valuation study. Environ Resour Econ 33:399-423. doi:10.1007/s10640-005-3606-0

Leigh JP (1995) Compensating wage, value of a statistical life, and inter-industry differentials. J Environ Econ Manage 28:83-97. doi:10.1006/jeem.1995.1006

Liu J-T, Hammitt JK (1999) Perceived risk and value of workplace safety in a developing country. J Risk Res 2:263-275. doi:10.1080/136698799376835

Liu J-T, Hammitt JK, Liu J-L (1997) Estimated hedonic wage function and value of life in a developing country. Econ Lett 57:353-358. doi:10.1016/S0165-1765(97)00238-3

Liu J-T, Hammitt JK, Wang J-D, Tsou M-W (2005) Valuation of the risk of SARS in Taiwan. Health Econ Lett 14:83-91. doi:10.1002/hec.911

Mrozek JR, Taylor LO (2002) What determines the value of life? A meta-analysis. J Policy Anal Manage 21:253-270. doi:10.1002/pam.10026

National Bureau of Statistics P. R. C. (1996) China statistical yearbook. China Statistics Press, Beijing

National Bureau of Statistics P. R. C. (2003) China labor statistical yearbook. China Statistics Press, Beijing

Olson AC (1981) An analysis of wage differentials received by workers on dangerous jobs. J Hum Resour 16:167-185. doi:10.2307/145507

Purse K (2004) Work-related fatality risks and neoclassical compensating wage differentials. Camb J Econ 28:597-617. doi:10.1093/cje/28.4.597

Riskin C, Zhao R, Li S (2000) Chinese household income project, 1995 [computer file]. ICPSR version. University of Massachusetts, Political Economy Research Institute [producer], Amherst, 2000; Inter-University Consortium for Political and Social Research [distributor], Ann Arbor

Rosen S (1974) Hedonic prices and implicit markets: product differentiation in pure competition. J Polit Econ 82:34-55. doi:10.1086/260169

Siebert WS, Wei X (1998) Wage compensating for job risks: the case of Hong Kong. Asian Econ J 12:171-181. doi: $10.1111 / 1467-8381.00058$

Smith A (1776) The wealth of nations. University of Chicago Press, Chicago

State Administration of Work Safety and State Administration of Coal Mine Industry, P. R. C. (2000-2002) China's work safety yearbook. Coal Mine Industry Press, Beijing

Stevens G, Wilson AM, Hammitt JK (2005) A benefit-cost analysis of retrofitting diesel vehicles with particulate filters in the Mexico City metropolitan area. Risk Anal 25:883-899. doi:10.1111/j.1539-924.2005. 00650.x

Viscusi WK (1979) Employment hazards: an investigation of market performance. Harvard University Press, Cambridge

Viscusi WK (1980) Union, labor market structure, and the welfare implications of the quality of work. J Labor Res 1:175-192. doi:10.1007/BF02685204

Viscusi WK (2004) The value of life: estimates with risks by occupation and industry. Econ Inq 42:29-48. doi:10.1093/ei/cbh042

Viscusi WK, Aldy JA (2003) The value of a statistical life: a critical review of market estimates throughout the world. J Risk Uncertain 27:5-76. doi:10.1023/A:1025598106257

Viscusi WK, Aldy JE (2007) Labor market estimates of the senior discount for the value of statistical life. J Environ Econ Manage 53:377-392. doi:10.1016/j.jeem.2006.10.005

Wang H, Mullahy J (2006) Willingness to pay for reducing fatal risk by improving air quality: a contingent valuation study in chongqing, China. Sci Total Environ 367:50-57. doi:10.1016/j.scitotenv.2006.02.049

World Bank (1997) Clear water, blue skies: China's environment in the new century. World Bank, Washington 